\title{
Honeybush (Cyclopia spp.) phenology and associated arthropod diversity in the Overberg region, South Africa
}

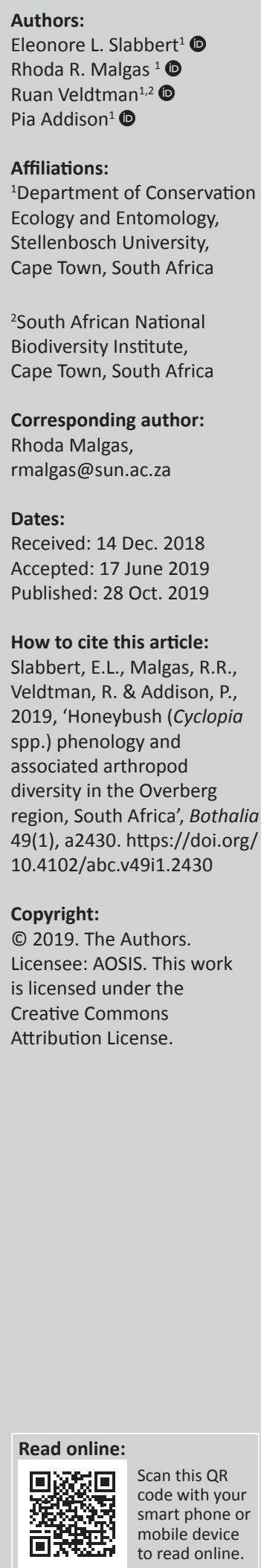

Background: Cyclopia is endemic to regions of the Cape Floristic Region across the Eastern and Western Cape provinces of South Africa and is commonly known as honeybush. Honeybush has historically been used as an herbal tea, and has proven medicinal properties. Honeybush biomass and extracts are used in the functional foods and cosmetics sectors, both locally and overseas. The growing demand for honeybush calls for increased agricultural production and a shift away from the predominantly wild harvested supply.

Objectives: The current study aimed to address the lack of baseline knowledge on honeybush phenology and its associated arthropod community to advance sustainable production of commercially valued plants in the genus.

Method: The study was conducted on wild and cultivated Cyclopia species (Cyclopia maculata and Cyclopia genistoides) at respective sites in the Overberg region. Sampling took place from April 2014 to April 2015 using qualitative methods for recording seasonal honeybush phenology and suction sampling for aboveground arthropods. Focal insect taxa (Coleoptera, Hemiptera, Thysanoptera, Lepidoptera and Hymenoptera) were sorted and identified to family level and classified into functional feeding guilds.

Results: Qualitative phenology observations of wild C. maculata and cultivated C. genistoides indicated a high level of congruency in seasonality of phenophase stages. Associated arthropod assemblages contained a diversity of families per functional feeding group, namely phytophagous, zoophagous and omnivorous taxa, with high seasonal variability.

Conclusion: Findings highlight the complexity of ecological elements to be taken into consideration for ecologically sound honeybush cultivation. Outcomes can be applied to land management practices and governance policies promoting sustainable agroecosystems in honeybush production areas.

Keywords: indigenous fynbos crop; resprouter; reseeder; Cyclopia phenology; arthropod biodiversity; agroecology; biodiversity-friendly cultivation.

\section{Introduction}

The Cape Fynbos genus Cyclopia (Fabeacea), generically referred to as honeybush, comprises 23 species, which make up to $0.28 \%$ of the approximately 9000 floral species and intraspecific taxa present in South Africa's Cape Floristic Region (CFR) (Goldblatt, Manning \& Snijman 2005; Manning 2018). Various Cyclopia species are endemic to coastal plains and mountainous areas within the CFR (Joubert et al. 2011; Van der Walt 2000), and species are distributed across the Western Cape and Eastern Cape provinces. Several of these are among the diverse plant species of South Africa's Fynbos, a fire-driven vegetation complex rich with species recognised for their human-use value. Although 11 species have been recorded for their use as herbal teas (Van Wyk \& Gorelik 2016), six Cyclopia species are harvested for commercial or livelihood purposes (Joubert et al. 2011). These are Cyclopia genistoides, Cyclopia intermedia, Cyclopia sessifloria, Cyclopia maculata, Cyclopia subternata and Cyclopia longifolia (Du Toit, Joubert \& Britz 1998; Joubert et al. 2011). Earliest records of the use of honeybush for brewing a hot tea-like beverage by local inhabitants dates back to the 1700s, as recorded by Thunberg during his botanical explorations at the Cape (Smith et al. 1996 as reported by Joubert et al. 2008). Different species of honeybush are also recognised for their medicinal value (Joubert et al. 2008, 2011; Kies 1951; Van Wyk 2008, 2011); these include, for example, the use of C. subternata for the treatment of diabetes (Dudhia et al. 2013; Larsen et al. 2011).

Honeybush biomass is either cultivated or wild harvested, with wild harvesting estimated to account for up to $80 \%$ of supply (McGregor 2017a). The honeybush industry has grown steadily over the past two decades (Department of Agriculture, Forestry and Fisheries (DAFF) 2014; 
Joubert et al. 2011) with potential to expand even further in both local and international markets (Coega Development Corporation (CDC) 2011; DAFF 2014). For the industry to expand and exploit its potential in the global herbal tea market, a shift from wild harvesting to cultivation is needed (Coetzee 2012; Den Hartigh 2011). Current cultivation practices yield between 10 and 40 tons per hectare, depending on the species, environmental factors and methods of cultivation (McGregor 2017a). Harvest frequencies, harvest season, harvesting methods and processing are all dependent on the types of species in question, as these are, in turn, affected by phenology, life history traits, rates of productivity and plant architecture.

Classification of honeybush into reseeders and resprouters according to their fire-survival strategy (Joubert et al. 2011; Schutte, Vlok \& Van Wyk 1995) offers helpful insights in light of their responses to other disturbance, such as harvesting and pests. Similar classifications can be made for sister species, Aspalathus linearis (Burm. F. Dahlg., Fabeacea) (rooibos), where ecotypes with different life history traits have been demonstrated to be ecologically distinct (Hawkins, Malgas \& Biénabe 2011). Reseeders propagate from seeds triggered to germinate by heat and smoke during fire. Resprouters not only re-produce from seed, but are also able to regenerate from meristematic tissue in the underground stem, or lignotuber (Bond \& Midgely 2001). Reseeders are typically tall and slender plants, with fast growth, prolific seed set and high biomass yield. By comparison, resprouters tend to have low, prostrate growth forms, with slower growth rates, fewer seeds and less aboveground biomass (Bond \& Midgely 2003; Clarke et al. 2013). Current literature further suggests that the rate of development differs among and between fire survival strategies (Bond \& Midgley 2001; Pierce 1984; Wardell-Johnson 2000). Longer-lived resprouters generally have a slower rate of development compared with reseeders (Bond \& Midgley 2001; Wardell-Johnson 2000). Consequently, phenological differences between reseeding and resprouting populations, whether wild or cultivated, have implications for production schedules and sustainable harvesting protocols, with certain faster growing reseeding species (e.g. C. maculata and C. subternata) harvested more regularly than slower growing resprouter counterparts (e.g. C. genistoides and C. intermedia). Wild harvesting occurs on an ad hoc basis, with some populations and some species more highly exploited than others (McGregor 2017b). Wild stands of C. maculata included in this study were only occasionally harvested, while the cultivated stands of C. genistoides were harvested annually or on a two to three year rotation. Although Cyclopia morphology has been studied both in the wild (Schutte 1997) and in cultivated stands (Spriggs \& Dakora 2009), only general observations are available of the phenology of some species. However, the historical practice of harvesting this species with its characteristically flavourful flowers sets the preferred harvest season at spring, between September and November, when flowers are present. Depending on the species, plants may grow between 0.5 to more than $2.5 \mathrm{~m}$ tall; harvest offtake is anything between $70 \%$ and 90\% (McGregor 2017b). McGregor (2017b), for instance, reported that $C$. intermedia in the Bo-Kouga was harvested to $12-15 \mathrm{~cm}$ aboveground from an estimated height of $115 \mathrm{~cm}$. Honeybush is still considered a fairly new crop with significant room for agronomic improvement and successful cultivation. Fundamental knowledge of the phenology and ecology of the genus is one of the knowledge gaps (Motsa et al. 2016), and one this research seeks to address.

In general, plant phenology and insect development are closely linked to biotic factors and are often well synchronised (Ascerno 1991; Forrest \& James 2011). Therefore, understanding plant phenology can inform prediction of insect development or migration within or between host plants (Ascerno 1991; Baumgartner Brandmayr \& Manly 1998), an important factor in managing agricultural pests. Investigating relationships between plant and insect phenology also helps to understand the complexity of ecological resource networks in agricultural production systems. Understanding these connections is especially important for indigenous crops, such as rooibos and honeybush, as it can inform plantation management by highlighting periods when plants would be most vulnerable to insect attack. These insights would aid decision-making for integrated pest management (IPM) activities.

Apart from implications for IPM, understanding the life histories of honeybush reseeders and resprouters is essential for making informed decisions regarding harvesting regimes and conservation actions pertaining to the genera, their habitats and associated biodiversity. Accurately capturing and analysing the phenology and life history of a species or vegetation type is not a simple task given the complex interaction between external abiotic and intrinsic biotic factors. This study aimed to investigate and determine the phenology of two commercially relevant Cyclopia spp., namely C. maculata and C. genistoides, in relation to insect diversity and abundance across phenological stages. Results of this study should serve as a guideline for future, more detailed, phenology studies, and form a baseline from which management decisions can be made regarding wild and commercial harvesting practices and conservation of the species. The detailed outline of phenological differences and similarities between the two Cyclopia species provides insight into the variability and diversity of the plants and their associated insect assemblages. Findings also highlight the potential arthropod-mediated ecosystem services (e.g. natural biological control agents) and disservices (e.g. potential insect pests) available to farmers engaged in honeybush production.

\section{Materials and methods Study design and setting}

Three study areas were selected in the Overberg region near the towns of Genadendal, Bredasdorp and Pearly Beach, where Cyclopia spp. grow either wild or under cultivation (Figure 1, Table 1). Study sites included either C. maculata 


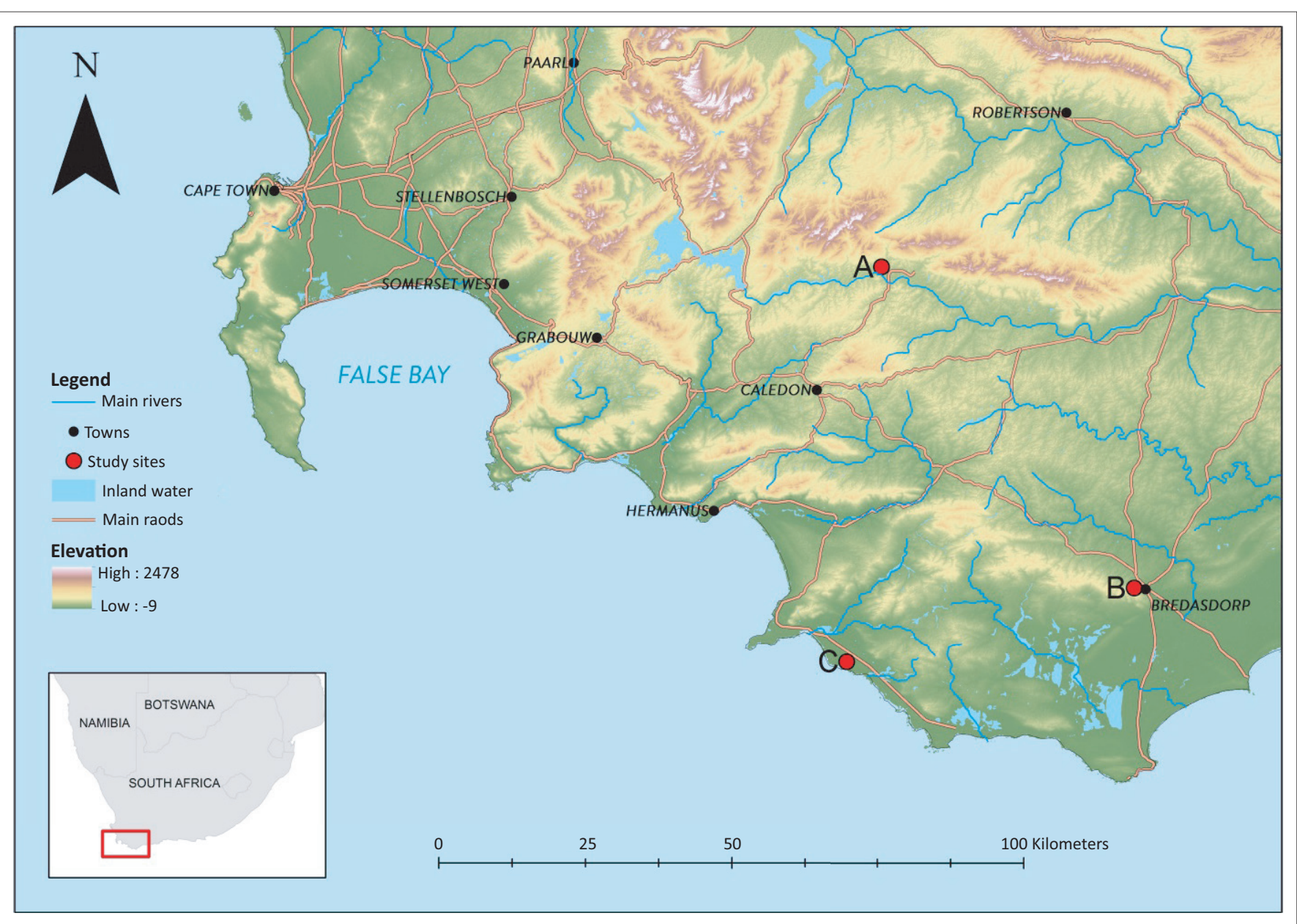

FIGURE 1: Study areas for investigating Cyclopia spp. phenology and their associated arthropod community were located within the Overberg district of the Western Cape, South Africa, in the vicinity of Genadendal (A), Bredasdorp (B) and Pearly Beach (C).

TABLE 1: Study area descriptions of three sites where either wild or cultivated Cyclopia species grow, field sites in the Overberg, South Africa.

\begin{tabular}{|c|c|c|c|c|c|c|c|}
\hline Study area & $\begin{array}{l}\text { Cyclopia spp. } \\
\text { (common name) }\end{array}$ & $\begin{array}{l}\text { Study area } \\
\text { description }\end{array}$ & $\begin{array}{l}\text { Harvest regime and } \\
\text { management practice }\end{array}$ & $\begin{array}{l}\text { Size of } \\
\text { population }\end{array}$ & $\begin{array}{l}\text { Natural vegetation } \\
\text { (conservation status) }\end{array}$ & Nearest town & $\begin{array}{l}\text { †PS } \\
\text { cocoordinates }\end{array}$ \\
\hline A & $\begin{array}{l}\text { C. maculata } \\
\text { ('Vlei' tea) }\end{array}$ & $\begin{array}{l}\text { Natural wild populations } \\
\text { with low disturbance. Sites } \\
\text { are located on low lying } \\
\text { land in vlei or marsh-type } \\
\text { areas. }\end{array}$ & $\begin{array}{l}\text { Wild population that } \\
\text { is occasional } \\
\text { harvested on an ad } \\
\text { hoc basis. }\end{array}$ & $\pm 0.2-0.5$ ha & $\begin{array}{l}\text { Central Ruens Shale } \\
\text { (FRs12) (Critically } \\
\text { Endangered). Several } \\
\text { sites heavily invaded } \\
\text { with Port Jackson. }\end{array}$ & $\begin{array}{l}\text { Genadendal and } \\
\text { surroundings }\end{array}$ & $34^{\circ} 05^{\prime} \mathrm{S} 19^{\circ} 41^{\prime} \mathrm{E}$ \\
\hline B & $\begin{array}{l}\text { C. genistoides } \\
\text { ('Kus tee'/coastal tea) }\end{array}$ & $\begin{array}{l}\text { Semi-natural cultivated } \\
\text { plantation with a moderate } \\
\text { level of disturbance. }\end{array}$ & $\begin{array}{l}\text { Harvest events on a } \\
2 / 3 \text { year rotation. } \\
\text { Ground cover } \\
\text { occasionally } \\
\text { managed by a } \\
\text { chemical 'burn'. }\end{array}$ & \pm 45 ha & $\begin{array}{l}\text { Overberg Sandstone } \\
\text { Fynbos (FFs12) (Least } \\
\text { Threatened) }\end{array}$ & Bredasdorp & $34^{\circ} 33^{\prime} \mathrm{S} 19^{\circ} 53^{\prime} \mathrm{E}$ \\
\hline C & $\begin{array}{l}\text { C. genistoides } \\
\text { ('Kus tee'/coastal tea) }\end{array}$ & $\begin{array}{l}\text { More traditional cultivation } \\
\text { practice with a high level of } \\
\text { disturbance. }\end{array}$ & $\begin{array}{l}\text { Annual harvest } \\
\text { (January/February). } \\
\text { Regular clearing of } \\
\text { ground cover } \\
\text { vegetation. }\end{array}$ & \pm 25 ha & $\begin{array}{l}\text { Natural vegetation, } \\
\text { Agulhas Sand Fynbos } \\
\text { (FFd7) (Vulnerable) }\end{array}$ & Pearly Beach & $34^{\circ} 41^{\prime} \mathrm{S} 19^{\circ} 35^{\prime} \mathrm{E}$ \\
\hline
\end{tabular}

$\dagger$, Global positioning system (GPS) locations are given at coarse resolution for protection of the communal or private resources.

(reseeder) or C. genistoides (resprouters), allowing for a life history comparison between the two, and more specifically a comparison of the phenology and related seasonal variation of the insect assemblages associated with each of these honeybush species. The stand of wild C. maculata at Genadendal was less than 5 years old at the time of data collection, while the plantation of $C$. genistoides at Bredasdorp and Pearly Beach was between 8 and 12 years old. At each of the three study sites, four locations were selected for phenological observations and arthropod monitoring. The positions of sampling sites for the wild stands were determined by the distribution of Cyclopia populations across the study area. In the cultivated fields, sampling sites were placed at least $10 \mathrm{~m}-15 \mathrm{~m}$ from the edge of the plantation along the length of the field, adjacent to Fynbos vegetation. Sampling sites for the wild honeybush varied in size and proximity of individual plants, whereas the sites of cultivated stands were evenly spaced within the cultivated fields. Site placement at wild honeybush stands was restricted by changes in land use or the presence of dense stands of invasive alien trees, such as Port Jackson (Acacia saligna [Labill.] Wendl; pine [Pinus pinaster \{Aiton\}] and black wattle [Acacia mearnsii $\{$ De Wild\}]). 


\section{Recording honeybush phenology}

Field trials and observations took place on a monthly basis over a 12-month period to determine the seasonal variation of the insect assemblages and to track the phenological changes of C. maculata and C. genistoides. Experimental sites were demarcated during February and March 2014, with monitoring taking place between April 2014 and April 2015. Weather data (daily average temperature and average weekly rainfall) were sourced from the Agricultural Research Council (AgroClimatology Staff 2015) and averaged out to obtain bi-monthly records per study site for the monitoring period.

Qualitative observations of Cyclopia phenology were made throughout the course of the monitoring period, with more detailed descriptions of the two species' phenology being conducted every second month of the 12 month period (mid-winter, July 2014 to autumn, April 2015). This was performed to determine the breaking of bud dormancy and the initiation of the reproductive and fruiting phases (Pierce 1984). For each of these detailed observations, 10 bushes were randomly selected within the demarcated sites. Distinct life history phases were recorded and average percentage new growth estimated from the top $10 \mathrm{~cm}$ of five branches per bush. Only the unharvested honeybush stands near Genadendal (four sites) and Bredasdorp (three sites) were used to compare plant phenology between C. maculata and C. genistoides. In total, the phenology of 240 C. maculata and 180 C. genistoides bushes was recorded over the course of the study. From these observations, a phenogram (phenology Gantt chart, Figure 2) was compiled, as well as a table detailing the transition between phenological phases (Table 1-A1). The percentages of plants within the population currently in the respective growth phases, at the time of observation, were also recorded (Pierce 1984).

\section{Arthropod collection and identification}

Insects were collected by suction sampling methods, using a leaf blower (Stihl, Pietermaritzburg, KwaZulu-Natal, South Africa, BG 55 model) with a reversed engine (d-vac sampling). Ten bushes were randomly selected at each site, and ten suctions were conducted per bush during each sampling period. Specimens were placed in labelled re-sealable bags and stored in a cooler box subsequent to freezer storage before further processing.

In the laboratory, specimens were identified to family level, and then into functional feeding guilds including zoophagous predators and parasitoids (Gess \& Gess 2014; Goulet \& Huber 1993; Prinsloo 1980, 1984; Stevens et al. 2007); phytophagous sap feeders, external (foliage) feeders, internal (stem, root and seed) feeders and other (nectar and pollen feeders) (Hatting 2009, 2015; Scholtz \& Holm 1985); omnivorous (diverse feeders of insects and plant material) (Scholtz \& Holm 1985); and fungivores, detritivores and scavengers (Scholtz \& Holm 1985) were grouped into an 'other' category (these were not included in analyses as these guilds do not directly impact on biomass production). Lepidoptera and Coleoptera larvae were classified as either being defoliators, internal or diverse feeders, depending on the specific taxon's feeding characteristics. Insects were collected from both mature and recently harvested stands of Cyclopia with the goal to identify periods of pest risk along the phenological timeline of mature and recently harvested plants.

Insect specimens were stored in 99\% ethanol. A reference collection of relevant specimens is housed at the entomological museum in the Department of Conservation Ecology and Entomology at Stellenbosch University and the ARC-Plant Protection Research Institute, South Africa.

\section{Data analysis}

Accumulation curves were drawn to determine sampling effort and to assess family richness, using Estimate STM v.8.2.0 software (Colwell 2013). Accumulation curves were drawn to family level with multiple sample-based rarefaction without replacement. Samples were then randomised 24 times to double the sampling effort (Colwell 2013). Abundance (number of individuals), richness (number of families) and diversity indices were calculated to family level for the insect assemblage per study area. Calculated estimate richness $(d)$ (i.e. estimate number of insect families), evenness (i.e. relative abundance of insect families, using Simpson-inverse $[1 / D]$ ) and diversity (Shannon-Weiner $\left[H^{\prime}\right]$, which accounts for both abundance and evenness) indices were used with the standard family abundance and richness counts to assess community complexity (DeClerck \& Salinas 2011).

Count data were generally not normally distributed and are therefore associated with a Poisson distribution. Plots of the raw residuals, however, showed normality for several of the data sets. Repeated measures analysis of variance (ANOVA) was used with restricted maximal likelihood (REML) to test for significant differences in the abundance and richness of functional feeding guilds over the three study areas and over the study period. The sample plots (e.g. four plots per study area) were nested as random effects within the study areas. Where raw residual plots indicated non-normal distribution, a square-root transformation was performed or bootstrap multiple comparisons were performed on the original results comparing the means if the transformation did not adequately correct for non-normal distributions. Sampling periods with missing data (because of harvest events) were omitted from the analysis. Post-hoc least squares distance (LSD) comparisons or bootstrap multiple comparisons were conducted on the original scores. The same statistical analyses were performed on the estimated richness, evenness and diversity indices. Analysis of variance analyses were performed in Statistica version 12 (Statsoft Inc. 2012).

\section{Ethical considerations}

No ethical clearance for interaction with people was sought for this project. Although we were guided by interactions 
with farmers, no data were collected from interviews or surveys, or other such research instruments.

\section{Results \\ Cyclopia spp. phenology}

Results indicated a high level of congruency in phenology between wild C. maculata (reseeder) and cultivated C. genistoides (resprouter) (Figure 2). Similarity was evident in the timing of the phenological cycles of the two honeybush species, with only some variation in the duration of life history phases or the specific week in which transition between life history phases occurred, as in the example of transition from flower senescence to fruit set (Figure 2).

Cyclopia maculata initiated floral budding (Figure 3a-b) much earlier (late autumn) than C. genistoides (early winter) (Figure 2). Floral bud development for C. maculata was, however, delayed by several weeks with bud development only evident in June (Figure 2). Floral buds matured towards the end of winter. Cyclopia genistoides was observed to have a more rapid floral bud development, with floral buds first appearing in June and then maturing to pre-anthesis by early September (Figure 2). The delay in bud development in C. maculata prolonged this life phase, doubling the time period in comparison to C. genistoides.

Both C. maculata and C. genistoides started their flowering period in September with a mosaic of bushes ranging from early bloom to late floral budding (Figure 2). Cyclopia genistoides was the first to start flowering (first week in September) and transitioned into peak bloom (Figure 3c-d) over a shorter period of time than C. maculata. Despite the time lag for bud development in C. maculata, the peak flowering period for both species was within the first two weeks of October (Figure 2). Both honeybush species had $70 \%-90 \%$ of the population in full bloom by the second week of October (Figure 2 and Table 1-A1). Floral senescence and seed set commenced approximately at the same time for both species forming swollen pods of $\pm 3 \mathrm{~cm}$ long from late October

\begin{tabular}{|c|c|c|c|c|c|c|c|c|c|c|c|c|}
\hline C. maculata & Apr & May & Jun & Jul/Aug & Sep & Oct & Nov & Dec & Jan & Feb & Mar & Apr \\
\hline New growth & & & & $\begin{array}{l}\text { Initial leaf } \\
\text { buds }\end{array}$ & & & Initial new leaf & canopy & & & & \\
\hline $\begin{array}{l}\text { Flower bud } \\
\text { formation }\end{array}$ & $\begin{array}{l}\text { Initial floral } \\
\text { budding }\end{array}$ & & $\begin{array}{l}\text { Newly } \\
\text { formed } \\
\text { floral buds }\end{array}$ & $\begin{array}{l}\text { Developing } \\
\text { and mature } \\
\text { buds }\end{array}$ & $\begin{array}{l}\text { mature } \\
\text { buds floral }\end{array}$ & & & & & & & $\begin{array}{l}\text { Initial } \\
\text { budding }\end{array}$ \\
\hline Flowering & & & & & $\begin{array}{l}\text { Initial bud } \\
\text { break }\end{array}$ & $\begin{array}{l}\text { Early (1st week)- } \\
\text { peak ( } 2 \text { nd-3rd } \\
\text { week) bloom. } \\
\text { senescence } \\
\text { (3rd-4th week) }\end{array}$ & & & & & & \\
\hline Seed set & & & & & & $\begin{array}{l}\text { Initial pod } \\
\text { development } \\
\text { (3rd/4th week) }\end{array}$ & $\begin{array}{l}\text { Pod } \\
\text { development; } \\
\text { mature } \\
\text { green pod } \\
\text { (2nd week); } \\
\text { pods ripen } \\
\text { (2nd-3rd week) }\end{array}$ & $\begin{array}{l}\text { Ripened } \\
\text { seed pods } \\
\text { (1st week) } \\
\text { ) }\end{array}$ & & & & \\
\hline Seed release & & & & & & & & $\begin{array}{l}\text { All pods } \\
\text { open by } 2 \text { nd } \\
\text { week }\end{array}$ & & & & \\
\hline Senescence & & & & $\begin{array}{l}\text { Mature leaf } \\
\text { progressive }\end{array}$ & $\begin{array}{l}\text { f canopy star } \\
\text { ely at a fast ra }\end{array}$ & $\begin{array}{l}\text { ts to thin out } \\
\text { ate }\end{array}$ & & $\begin{array}{l}\text { Varying \% of } \\
\text { canopy rema }\end{array}$ & $\begin{array}{l}\text { f old leaf } \\
\text { aining }\end{array}$ & & & \\
\hline C. genistoides & Apr & May & Jun & Jul/Aug & Sep & Oct & Nov & Dec & Jan & Feb & Mar & Apr \\
\hline New growth & & & & & & Initial leaf buds & $\begin{array}{l}\text { Canopy still } \\
\text { dominated by } \\
\text { old mature } \\
\text { leaves }\end{array}$ & & & & & \\
\hline $\begin{array}{l}\text { Flower bud } \\
\text { formation }\end{array}$ & & & $\begin{array}{l}\text { Initial floral } \\
\text { budding }\end{array}$ & $\begin{array}{l}\text { Newly } \\
\text { formed } \\
\text { floral buds }\end{array}$ & $\begin{array}{l}\text { Mature } \\
\text { buds (1st } \\
\text { week) }\end{array}$ & & & & & & & \\
\hline Hlowerıng & & & & & $\begin{array}{l}\text { Early bloom } \\
\text { (1st-mosai } \\
\text { floral week } \\
\text { (2nd-bloon } \\
\text { (3rd/4th we }\end{array}$ & $\begin{array}{l}\text { Peak bloom } \\
\text { c (1st 2nd week), } \\
\text { ), full senescence } \\
\text { n 3rd week) } \\
\text { eek) }\end{array}$ & & & & & & \\
\hline Seed set & & & & & & $\begin{array}{l}\text { Initial pod } \\
\text { development } \\
\text { (2nd/3nd week) }\end{array}$ & $\begin{array}{l}\text { Pod } \\
\text { development } \\
\text { (1st-2nd week); } \\
\text { pods ripen } \\
\text { (3rd-4th week) }\end{array}$ & $\begin{array}{l}\text { Ripened } \\
\text { seed pods }\end{array}$ & & & & \\
\hline Seed release & & & & & & & & $\begin{array}{l}\text { All pods } \\
\text { popped by } \\
1 \text { st/2nd } \\
\text { week }\end{array}$ & & & & \\
\hline Senescence & & & & & & & $\begin{array}{l}\text { Gradual onset o } \\
\text { shedding }\end{array}$ & of leaf & & & & \\
\hline
\end{tabular}

FIGURE 2: Phenology and life history phases for wild Cyclopia maculata (reseeder) and cultivated Cyclopia genistoides(resprouter) in the Overberg region, South Africa, from April 2014 to April 2015. Life history phases (left hand column) colour codes across the two species. 


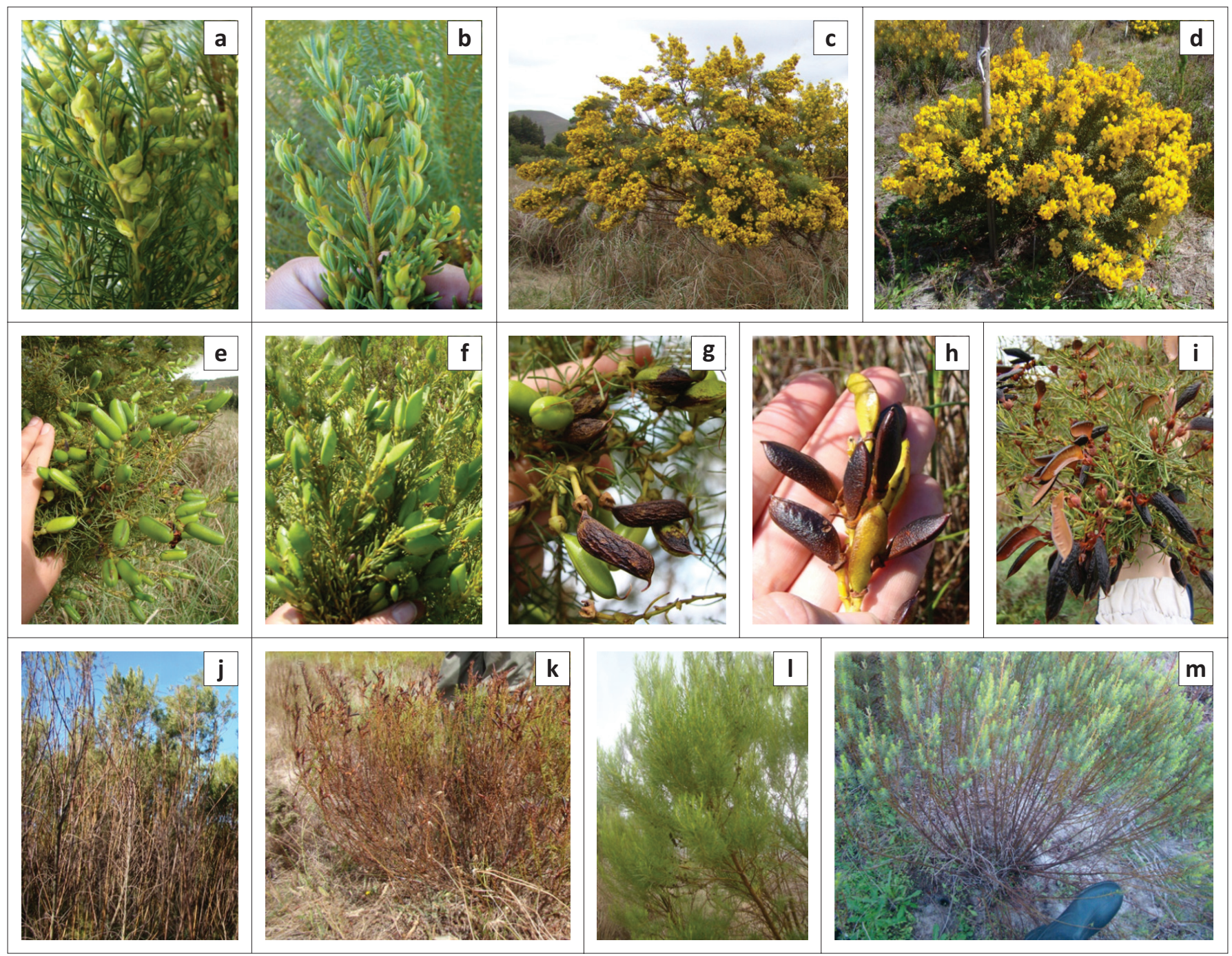

Source: Photos courtesy of Eleonore L. Slabbert (first author)

FIGURE 3: Phenology of Cyclopia maculata (2-3 m diameter $\times 1.5-3.0 \mathrm{~m}$ height) and C. genistoides (1.0-1.5 $\mathrm{m}$ diameter $\times \pm 1 \mathrm{~m}$ height) (consistently to the left- and right-hand side, respectively): The reproductive phases of (a)-(b) floral budding (June-August), (c)-(d) peak bloom (October), (e)-(f) fruiting and (g)-(h) pod ripening (November), (i) seed release (picture of Cyclopia maculata) and growth phases of (j)-(k) leaf shedding and new growth starting with a (I)-(m) summer flush. Observations were made from April 2014 to April 2015 at field sites in the Overberg, South Africa.

to November (Figure 3e-f). Cyclopia maculata commenced fruiting slightly earlier than C. genistoides as $20 \%-30 \%$ more of this population was already fruiting (seed set) by the second week of October (Table 1-A1). For both honeybush species, some seed pods were already ripe by mid-November (Figure 2 and Figure 3g-h). Ripening seed pods turned dark brown as the pods dried out. Once seed pods had ripened, they split open with a slight popping sound to release the mature seeds within. This action of bursting seed pods aids in seed dispersal. The majority of ripened seed pods had already split open by early or mid-December (Figure 3i).

Excessive leaf shedding was evident for both species (Figure 2, Figure 3j-k and Table 1-A1), with several bushes becoming completely defoliated before new leaf growth commenced with the summer flush (Figure 31-m), forming a new canopy in the following growing season. The main growth period for Cyclopia spp. was during the summer month's post-seed release. New leaf growth was initiated during late July for C. maculata, followed by C. genistoides four to six weeks later (Figure 2). Newly formed leaves dominated the canopy volume of $C$. maculata soon after floral senescence (November to December). In contrast, C. genistoides retained its old leaf canopy for a longer period and only started to show signs of leaf shedding by November (Figure 2). The transition for C. maculata from a canopy dominated by old mature leaves to one dominated by new leaf flush overlapped in some cases and was less common in occurrence for C. genistoides. Only by mid-summer (January), did C. genistoides have a restored leaf canopy of new growth.

Leaf bud dormancy was broken late in winter for C. maculata and in mid-spring for C. genistoides (Figure 2 and Table 1-A1). Both of these events corresponded to temperature increases or fluctuations during the seasonal transition from winter to spring (Figure $4 \mathrm{a}$ and $\mathrm{b}$ ). New leaf growth was also linked to average rainfall. For both $C$. maculata and C. genistoides, a distinct decrease was seen in the average percentage new leaf growth per branch by late summer (February) after the summer growth flush. This was followed by a doubling of 
the amount of new leaf biomass by April 2015 with the onset of an autumn growth flush (Figure 4a and b).

\section{Arthropods associated with Cyclopia spp. and their seasonality}

\section{Sampling effort}

During the course of this study, 21538 specimens from 130 families were collected by d-vac sampling. Focal group

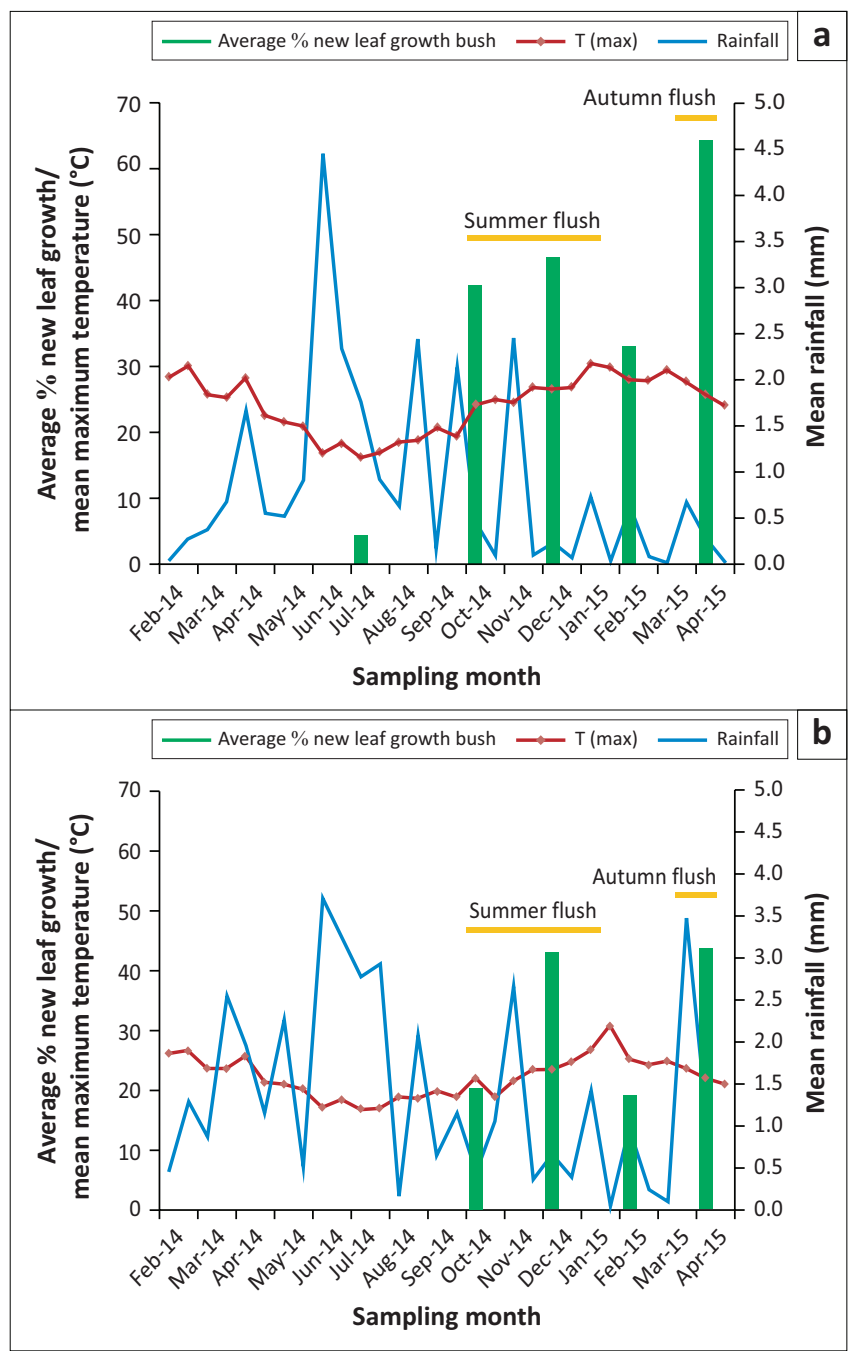

FIGURE 4: Average percentage new leaf growth (green bars on the primary $y$-axis) for (a) Cyclopia maculata and (b) Cyclopia genistoides with mean maximum temperature $\left({ }^{\circ} \mathrm{C}\right.$ ) (diamond marked line as second entry on the primary $y$-axis) and mean rainfall $(\mathrm{mm})$ for the study areas (on the secondary $y$-axis). Mean maximum temperature ( $T$ ) and rainfall are given on a bimonthly basis. Phenological observations were made every two months from late July 2014 to April 2015 on sites in the Overberg, South Africa. orders included in the analyses were selected because of their relevance to honeybush biomass production as either potential pests or natural predators (i.e. potential biological control agents). These included Coleoptera (beetles), Hemiptera (leafhoppers and aphids), Thysanoptera (thrips), Lepidoptera (moths and butterflies) and Hymenoptera (predatory and parasitoid wasps, and ants). Accumulation curves per study area indicated that sampling effort for the mature stand of C. maculata and the recently harvested C. genistoides were more representative of arthropod family richness than the mature stand of C. genistoides (figure not shown). The curve of the mature stand of $C$. genistoides was less asymptotic by 12 sampling periods than the other two study areas and had the highest overall estimated family richness from eight sampling rounds.

\section{Arthropod abundance and insect family diversity}

Abundance, evenness and diversity indices, for the mature stands of C. maculata and C. genistoides, showed high similarity in the recorded insect assemblages (Table 2). The new growth at the recently harvested $C$. genistoides study site had significantly higher calculated indices, namely estimated insect family richness, family evenness and diversity (Table 2).

\section{Seasonality of arthropod assemblages}

High seasonal variability for both C. maculata and C. genistoides was found within and between monthly sampling for family richness $(S)$, abundance $(N)$ and evenness $(1 / D)$ of the arthropod assemblage. Overall family richness $(S)\left(F_{(8,72)}=\right.$ 2.262, $p<0.05)$ of insects across the study areas was significantly different across the sampling periods. While family abundance $(N)\left(F_{(8,72)}=1.097, p>0.05\right)$ was not significantly different across the three study sites. Estimated family richness showed a similar pattern at the two mature Cyclopia stands, and generally had lower estimated family richness than that of the recently harvested C. genistoides stand (Figure 5a). However, overall, the three study areas were not significantly different in estimated family richness $\left(F_{(16,72)}=1.243, p>0.05\right)$.

Zoophagous arthropod abundance $\left(F_{(16,72)}=1.590, p>0.05\right)$ and family richness $\left(F_{(16,72)}=1.316, p>0.05\right)$ were not significantly different between the three honeybush stands. Overall, phytophagous family richness was significantly higher for the recently harvested $C$. genistoides $\left(F_{(2,9)}=9.807, p<0.05\right)$ study area in comparison to the mature stands of $C$. maculata and C. genistoides, respectively (Figure 5b). Phytophagous

TABLE 2: Mean diversity and richness indices (with respective standard errors, \pm SE) of the insect assemblage associated with Cyclopia species as sampled by d-vac from April 2014 to January 2015 in the Overberg region, South Africa.

\begin{tabular}{|c|c|c|c|c|c|}
\hline Index & C. maculata (M) & C. genistoides (M) & C. genistoides (NG) & $F_{(2,9)}$ & Sig \\
\hline Mean abundance $(N)$ & $111.97 \pm 19.43^{\mathrm{a}}$ & $90.81 \pm 19.43^{a}$ & $69.31 \pm 19.31^{a}$ & 1.206 & NS \\
\hline Family richness $(S)$ & $18.67 \pm 2.43^{\mathrm{a}}$ & $19.47 \pm 2.43^{\mathrm{a}}$ & $24.78 \pm 2.43^{\mathrm{a}}$ & 1.872 & NS \\
\hline Estimated richness $(d)$ & $2.43 \pm 0.21^{\mathrm{a}}$ & $2.82 \pm 0.21^{\mathrm{a}}$ & $3.78 \pm 0.21^{b}$ & 11.013 & $* *$ \\
\hline Evenness $(1 / D)$ & $0.70 \pm 0.03^{\mathrm{a}}$ & $0.71 \pm 0.03^{\mathrm{a}}$ & $0.83 \pm 0.03^{b}$ & 8.732 & $* *$ \\
\hline Diversity $\left(H^{\prime}\right)$ & $1.60 \pm 0.08^{\mathrm{a}}$ & $1.73 \pm 0.08^{\mathrm{a}}$ & $2.28 \pm 0.08^{b}$ & 18.588 & $* * *$ \\
\hline
\end{tabular}

Note: Indices reported include mean abundance $(N)$, family richness $(S)$, estimated family richness $(d)$, inverse of Simpson index as a measure of evenness $(1 / D)$ and the Shannon-Weiner diversity index $\left(H^{\prime}\right)$. Two study areas had mature (M) bushes of Cyclopia maculata (sites near Genadendal) and Cyclopia genistoides (sites near Bredasdorp), respectively, while the third study area (near Pearly Beach) consisted of recently harvested Cyclopia genistoides that was in its new growth (NG) phenological phase. Significant differences between study areas per index are indicated by the different alphabetical letters ${ }^{(a} a^{b} d^{b}$ along with the $F$-statistic and degrees of freedom (restricted maximal likelihood, least squares distance post hoc, confirmed with bootstrapping where necessary). $*, p<0.05 ; * *, p<0.01 ; * * *, p<0.001 ;$ NS, not significant. 


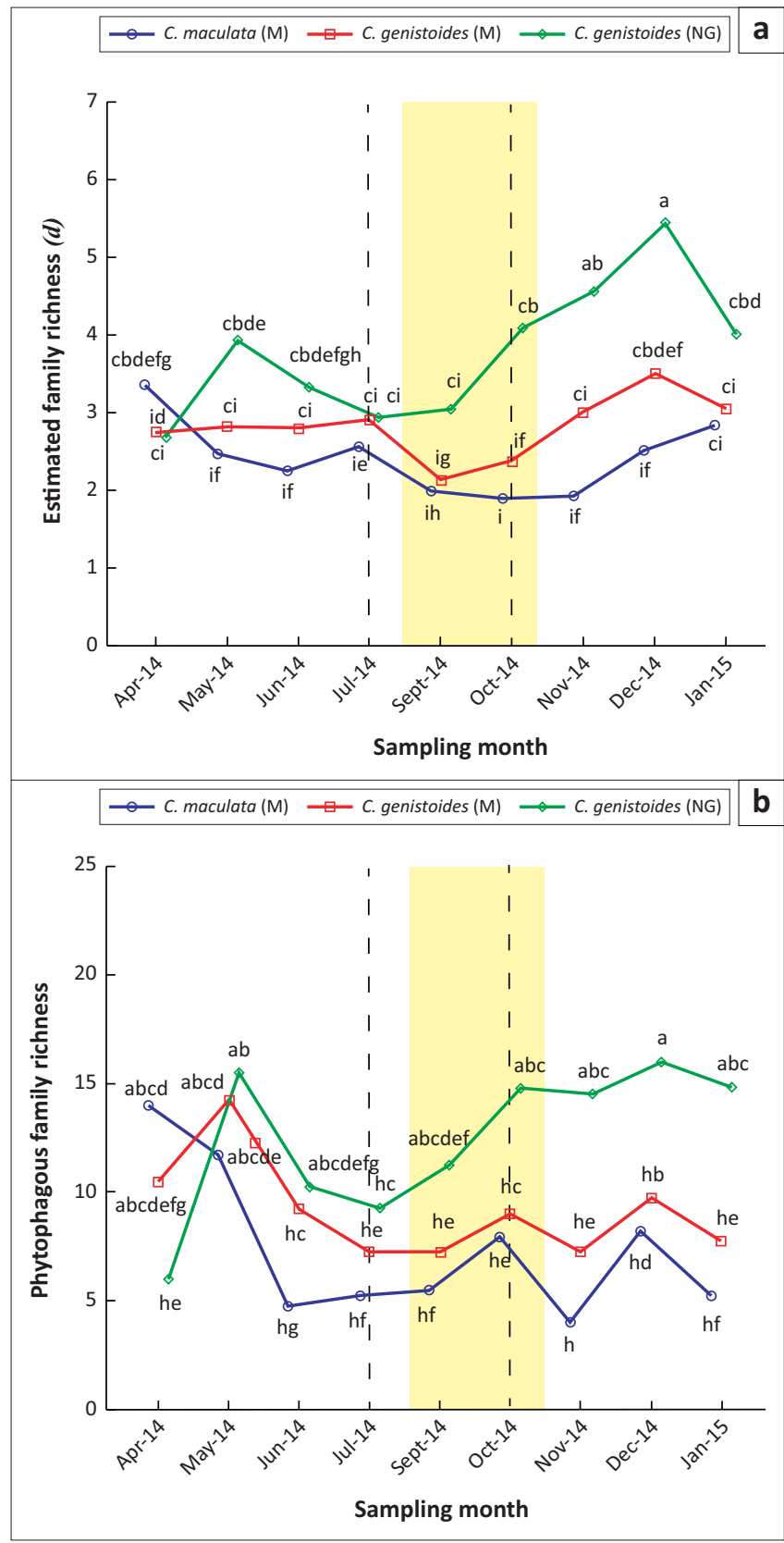

FIGURE 5: (a) Estimated family richness and (b) phytophagous family richness of the arthropod assemblage associated with mature (M) and new growth (NG) stands of Cyclopia spp. by d-vac sampling from April 2014 to January 2015, field sites in the Overberg, South Africa. Different alphabetical letters indicate significant differences within and across months (restricted maximal likelihood least squares distance post hoc). To simplify graph interpretation, 95\% confidence intervals have been omitted. The dashed lines indicate the initial lea budding for Cyclopia maculata (July/August) and Cyclopia genistoides (October) respectively. Fruiting is initiated in October for both species after the flowering period (yellow band) in September to October.

arthropod abundance peaked during the flowering period for the mature stands of Cyclopia, but overall, the three study areas were not significantly different $\left(F_{(16,72)}=1.423, p>0.05\right)$ from each other when comparing the combined means per month across the three study areas. Abundance and family richness of omnivorous arthropods were similar for all three study areas $\left(F_{(16,72)}=1.033, p>0.05\right.$ and $\left.F_{(16,72)}=0.560, p>0.05\right)$.

Estimated family richness sampled from April 2014 to January 2015 was not significantly different among the three study areas $\left(F_{(16,71)}=1.192, p>0.05\right)$. In October 2014, the family richness at the mature stand of $C$. genistoides was significantly lower $(p<0.05)$ than the recently harvested C. genistoides stand (Figure 5a). Likewise, family richness at the mature stand of $C$. genistoides was also lower than the other two honeybush stands, albeit not significantly so.

Phytophagous insect families that were especially abundant during the sampling period from April 2014 to April 2015 included several species of sap feeders (Hemiptera: Aphididae, Cicadellidae*; Thysanoptera: Thripidae); external foliage and seed feeders (Coleoptera: Buprestidae*, Bruchidae, Chrysomelidae, Curculionidae*; Lepidoptera: Ctenuchidae, Geometridae*, Lasiocampidae*, Noctuidae*, Pyralidae* and Tortricidae); internal feeders (Coleoptera: Apionidae, Tenebrionidae*); as well as diverse feeders (Coleoptera: Elateridae and Hymenoptera: Formicidae). Those marked with an asterisk (*) are known pests on rooibos (Hatting 2009). Abundant zoophagous insects (i.e. predators) included Coccinellidae, Anthicidae, Carabidae and a diversity of spiders and predatory mites (the latter two groups did not form part of the statistical analysis as they were only identified to order level). A diversity of Hymenoptera was also part of the zoophagous arthropod assemblage including both predator and parasitoid families, the latter being much more abundant and diverse. The most abundant predator wasp families included Pompillidae and Sphecidae, while parasitoids families commonly encountered included Platygastridae, Encyrtidae, Bethylidae, Ichneumonidae, Mymaridae and Eulophidae.

\section{Discussion}

The high degree of similarity between the phenologies of C. maculata and C. genistoides, despite their distinct life history traits, suggests some level of internal or endogenous cue for phenology transition. The potential of inherent cues in flowering events in Fynbos species was first recorded in the 1980s when transplanted Protea species maintained their natural flowering period despite being removed from their accustomed climatic conditions (Vogts 1982 in Pierce 1984). Similarity in the two Cyclopia species phenologies showed synchrony with prevailing weather conditions observed at both study areas, where rainfall and temperature showed similar trends. Further in-depth phenology studies are needed to determine the causal relationships between phenological phases, internal cues and climatic conditions for the Cyclopia genus. It would be especially insightful if cooccurring Cyclopia spp. of the same known age could be compared over time.

Moderate differences in the timing of phenological events for the two honeybush species could be ascribed to their distinctly different fire-survival strategies. The reseeder C. maculata was observed to be relatively short-lived in comparison to the resprouter, C. genistoides, with a portion of the much younger $C$. maculata population dying off towards the end of the field trials. This particular C. maculata stand was less than five years old in comparison with the 
older 12+ year old C. genistoides plantations. Similar observations have been made between cultivated reseeding rooibos and wild resprouter ecotypes in the Suid Bokkeveld (Louw 2006) and at Wupperthal between wild rooibos reseeders and resprouters (Malgas et al. 2010). As accounted for with succession theory, these reseeders are pioneer species, and are among the first to appear after fire (Kruger 1984; Power et al. 2011). By implication, they are short-lived, prolific growers, with high biomass output that may be harvested more frequently than slower growing resprouters. Harvesting after seedset would secure a seedbank in both reseeders and resprouters, but would be especially important for resprouters, because they produce fewer seeds. Species harvested with flowers (e.g. C. maculata) reduce the contribution of those plants to the seed bank, regardless of the life history strategy. Differences in plant longevity and development phases are also evident among other plant families in the Fynbos with distinct fire-survival strategies (Allen 2008), for example Ericaceae (Verdaguer \& Ojeda 2002) and Bruniaceae (Mustart 2000). The investment in the underground storage organ accounts for the slower growth rate reported for resprouters (Bond \& Midgely 2001), and the investment in reproduction is then seen in the earlier onset and a higher rate of development for C. maculata.

Overlap in the various phenophases of both Cyclopia species can be ascribed to general synchronicity within the plant community. Resource limitations, such as low nutrient soils, have been coupled to several Fynbos species having synchronised or overlapping growth and flowering stages (Pierce 1984). Adaptation to nutrient-poor soils, allowing for synchronised phenophases, however, does not necessarily suggest a resource limitation hindrance (Pierce 1984), but rather an adaptation of the genus to optimally utilise the limited resources available (Pilar \& Gabriel 1998). Habitat preferences of C. maculata (Table 1) suggest that it is well adapted to wetter conditions and seasonally waterlogged soils. Water resources are thus more readily available and explain the overlap of several high-energy demanding phenophases (Pilar \& Gabriel 1998). Cyclopia genistoides has more compact reproductive stages, suggesting adaptation to drier habitat conditions (Aronson et al. 1992). The distribution of reseeders and resprouters in mesic and arid areas, respectively, has been demonstrated for A. linearis (Hawkins et al. 2011), and for other Fynbos genera such as Ericacea (Ojeda et al. 1998) and Otholobium and Psoralea (Power et al. 2011). Synchrony and overlap of growth and flowering has also been recorded for several of the Protea and Leucadendron species, for example Protea neriifolia and Leucadendron cuneiform, among others (Le Maitre, pers. comm 1982 as referenced by Pierce 1984).

In the only other study on honeybush phenology, Motsa et al. (2016) reported that C. genistoides and C. subternata also generally had similar durations of reproductive phenophases, but in the onset of flowering, C. genistoides was delayed by up to three weeks, compared to that of the reseeder,
C. subternata. The overlap in flowering period for C. maculata and $C$. genistoides in this study raises the question whether these two species could potentially hybridise within mixed cultivated stands (Mallet 2008; Rieseberg 1997; Rieseberg \& Carney 1998). The cladistic analysis by Schutte (1997), based on morphology, suggested that C. maculata and C. genistoides are distant relatives, but more recent phylogenetic analysis revealed that most Cyclopia species are closely related (Boatwright et al. 2008). Several Cyclopia species, including C. maculata and C. genistoides, are currently being considered for cultivation (Joubert et al. 2011), which increases the potential risk of infield interspecific hybridisation (Mallet 2008). Although the genus is thought to have the same insect pollinators, presumably Carpenter bees: Anthophoridae, every pollen transfer does not necessarily translate to a successful pollination event. Indeed, populations of these two species naturally occur in close enough proximity for crosspollination to have been possible (considering dispersal limitations of the pollinator), yet no known viable hybrids have been recorded in the wild. Earlier in vitro studies (e.g. Bester \& De Lange 2010) with various Cyclopia species suggest that there is a strong selection against hybrid formation (less than 2\%: De Lange \& Von Mollendorf 2006). Nonetheless, should infield interspecific hybridisation take place (across wild and cultivated populations) substantial losses to genetic diversity may occur (Laikre et al. 2010; Seehausen et al. 2008). Implications for potential hybridisation of commercial honeybush species should be considered prior to cultivation beyond their natural range. Should hybridisation occur between wild and cultivated species, consequences would extend to jeopardising the persistence of wild populations used for local livelihood purposes. Some of these concerns and their ecological implications are explored by Potts (2016).

Patterns in new leaf growth suggest two main active leaf growth periods, namely a summer and autumn growth flush. These observations support the overall growth patterns noted in studies by Pierce (1984) during the Fynbos Biome Project. The unique climatic conditions in the Cape (Esler, Pierce \& De Villiers 2014) are potentially the cause for this deviation from the general trend observed in similar vegetation types (Cody \& Mooney 1978). Bond (1980) similarly found Protea species with a summer growth regimen to be more adapted to a summer rainfall or non-seasonal rainfall regions. The Overberg is one such region with nonseasonal rainfall (Esler et al. 2014) and current phenology observations suggest that C. maculata and C. genistoides (whether wild or cultivated) are similarly adapted to these biophysical conditions. Knowledge of growth flushes in these commercially important species offers important cues for land-use practices and harvest schedules for honeybush producers. Phenological triggers and seasonality also hold implications for how land users may respond to the pervasive effects of climate change in honeybush production systems.

As winter draws to an end and temperatures rise, both Cyclopia phenology and insect activity transitioned from a period of winter dormancy towards an active state of 
development. Increased insect activity corresponded with an increase in temperature (Danks 1994; Forrest \& James 2011; Snodgrass et al. 2012; Son 1999) and available food resources (Snodgrass et al. 2012; Willmer \& Stone 2004). As anticipated, aspects of Cyclopia phenology (e.g. active growth) were also found to be synchronised to temperature increases (Ascerno 1991; Atkinson \& Porter 1996) and could thus serve as an indicator of insect emergence (Ascerno1991; Forrest \& James 2011; Snodgrass et al. 2012). Insect infestation generally increases during susceptible crop growth stages (i.e. new leaf growth) and is accentuated by higher temperatures (Sivertsen et al. 1999). The summer and autumn growth flush phases are thus potential pest risk periods for Cyclopia. Fruiting (seed set), from October to November, is another pest risk period where seed pods can become heavily infested by various taxa, for example weevils and apionids.

Insect richness and evenness was lower during the flowering period and consisted predominately of Coleopterans (Chrysomelidae and Scarabaeidae). The decrease in family evenness was more pronounced for the mature stand of cultivated C. genistoides because of the much larger area covered by flowering shrubs. The other flowering stand of C. maculata revealed less fluctuation in family evenness as the wild stands cover a smaller area and are not as densely populated as the cultivated field of C. genistoides. The significantly higher family richness of phytophagous insects at the recently harvested C. genistoides study area suggests that new growth is targeted by herbivorous insects which could potentially negatively affect plant health (e.g. disease transmission) and decrease growth vigour (Collinge \& Louda 1989; Sivertsen et al. 1999). Additional variability of weather conditions, such as temperature, could further increase risk of crop infestation during susceptible stages of new growth (Sivertsen et al. 1999). Several of the most abundant phytophagous insect families associated with Cyclopia could potentially become agricultural pests of cultivated honeybush considering the pest status that several of these families have within the rooibos industry (Annecke \& Moran 1982; Hatting 2009, 2015; Rust \& Myburgh 1989). These potential pests and the suite of potential natural biological control agents (e.g. from the diverse array of predatory and parasitoid insects families recorded) require further investigation for optimising on potential arthropod-mediated ecosystem services for IPM available for honeybush production.

\section{Conclusion}

When making decisions regarding when and how often to harvest Cyclopia species or how to manage crop production in the context of IPM, ecological factors such as fire-survival strategies and phenology of the host crop are important to consider. Cyclopia maculata as a non-resprouter is less likely to respond favourably to excessive harvesting or insect damage, or any other disturbance, while C. genistoides, as a resprouter, is adapted to regrow after disturbance that result in the loss of its foliage biomass. This adaptation makes C. genistoides more suited for regular harvesting, and likely more resistant to insect pest damage, bearing in mind that plants require sufficient time to replenish their rootstock reserves after harvest. Regular annual harvesting is thus potentially not ideal for maintaining longevity, optimising on biomass production and maintaining plant resilience against disease and insect pests. As with $A$. linearis resprouters, harvesting once every second or third year is more desirable. This is common practice among members of rooibos communities who do wild harvesting of rooibos (Louw 2006)

Early monitoring of insect populations within honeybush plantations is recommended, especially in view of the potential pests and the increase in phytophagous richness at the one cultivated stand of C. genistoides. The role of natural biological control agents of potential arthropod pests requires further investigation as these could be valuable as an ecosystem service of pest control within cultivated Cyclopia plantations.

\section{Acknowledgements}

The support and input of the respective small- and largescale honeybush farmers are acknowledged with gratitude. The authors thank Prof. Henk Geertsema and Dr René Gaigher for their assistance with insect identifications. They also thank Prof. Daan Nel who made valuable contributions with regard to data analysis and Dr Gerard Francois Hermanus van Ginkel Bekker for producing the study area map.

\section{Competing interests}

The authors declare that they have no personal or financial gain or relationships that might have inappropriately influenced them in writing this article.

\section{Authors' contributions}

E.S. and R.R.M. conceived the study through discussion with farmers. All authors contributed to developing and refining the overall research approach. E.S. developed the sample design and collected the data under guidance of the other authors. E.S. did the main data analyses and wrote the draft of the manuscript, with R.R.M., R.V. and P.A. who all contributed substantially to revisions

\section{Funding}

This research was made possible through the financial support of the National Research Foundation (NRF) (Innovation Fund); the Western Cape Department of Agriculture, Forestry and Fisheries (DAFF) (Alternative Crop Fund); the South African National Biodiversity Institute (SANBI); the Netherlands Initiative for Capacity in Higher Education (NICHE) and Stellenbosch University.

\section{Data availability statement}

The raw data generated during this study are not yet freely available because of further planned publications. 


\section{Disclaimer}

The views and opinions expressed in this article are those of the authors and do not necessarily reflect the official policy or position of any affiliated agency of the authors.

\section{References}

AgroClimatology Staff, 2015, ARC-ISCW climate information system, ARC-Institute for Soil, Climate and Water, Pretoria, South Africa.

Allen, H.D., 2008, 'Fire: Plant functional types and patch mosaic burning in fire-prone ecosystems', Progress in Physical Geography 32(4), 421-437. https://doi. org/10.1177\%2F0309133308096754

Annecke, D.P. \& Moran, V.C., 1982, Insects and mites of cultivated plants in South Africa, pp. 302-302, Butterworth (SA) (Pty), Ltd, Durban.

Aronson, J., Kigel, J., Shmida, A. \& Klein, J., 1992, 'Adaptive phenology of desert and Mediterranean populations of annual plants grown with and without wate stress', Oecologia 89(1), 17-26. https://doi.org/10.1007/BF00319010

Ascerno, M.E., 1991, 'Insect phenology and integrated pest management', Journal of Arboriculture 17(1), 13-15. https://agris.fao.org/agris-search/search.do?recordID= US19920074949

Atkinson, D. \& Porter, J.R., 1996, 'Temperature, plant development and crop yields', Trends in Plant Science 1(4), 119-124. https://doi.org/10.1016/S1360-1385(96)90006-0

Baumgartner, J., Brandmayr, P. \& Manly, B.F.J. (eds.), 1998, Population and community ecology for insect management and conservation, CRC Press Book, Rotterdam. ISBN 9054109300

Bester, C. \& De Lange, J.H., 2010, 'Genetic improvement of honeybush (Cyclopia spp.)' Abstract Book of the 8th Southern African Plant Breeders' Association (SAPBA) conference, Stellenbosch, South Africa, 16-17 March 2010.

Boatwright, J.S., Savolainen, V., Van Wyk, B., Schutte-vlok, A.L., Forest, F. \& Van der Bank, M., 2008, 'Systematic position of the anomalous genus Cadia and the phylogeny of the tribe Podalyrieae (of the anomalous genus Cadia) and the phylogeny of the tribe', Systematic Botany 33(1), 133-147. https://doi. org/10.1600/036364408783887500

Bond, W.J., 1980, 'Periodicity in fynbos of the non-seasonal rainfall belt', Journal of South African Botany 46(4), 343-354, viewed 10 March 2014, from https://agris. fao.org/agris-search/search.do?recordID=US201302788937.

Bond, W.J. \& Midgley, J.J., 2003, 'The evolutionary ecology of sprouting in woody plants', International Journal of Plant Sciences 164(S3), S103-S114, viewed 25 April 2014,
from https://userwww.sfsu.edu/parker/bio821/papers/Students2014/Keeley/ from https://userwww.sfsu.edu/parker/
Fire_resprouting_Bond\&Midgley2003.pdf.

Bond, W.J. \& Midgely, J.J., 2001, ‘Ecology of sprouting in woody plants: The persistence niche', Trends in Ecology and Evolution 16(1), 45-51. https://doi.org/10.1016/ S0169-5347(00)02033-4

Clarke, P.J., Lawes, M.J., Midgley, J.J., Lamont, B.B., Ojeda, F., Burrows, G.E. et al., 2013, 'Resprouting as a key functional trait: How buds, protection and resources drive persistence after fire', New Phytologist 197(1), 19-35. https://doi. org/10.1111/nph.12001

Cody, M.L. \& Mooney, H.A., 1978, 'Convergence versus non-convergence in Mediterranean-climate ecosystems', Annual Review of Ecology and Systematics 9 , 265-321. https://doi.org/10.1146/annurev.es.09.110178.001405

Coega Development Corporation (CDC), 2011, Honeybush industry has huge growth potential, viewed 02 May 2015, from https://www.coega.co.za/NewsArticle. potential, viewed 02
aspx?objID $=8 \&$ id $=47$.

Coetzee, J., 2012, 'Heuningbosteebedryf kan nog tienvoudig groei', Landbouweekblad (September), 44, viewed 15 March 2014, from https://www.sahoneybush.co.za/ media1/file/54-heuningbosteebedryf-kan-nog-tienvoudig-groei.html.

Collinge, S.K. \& Louda, S.M., 1989, 'Influence of plant phenology on insect herbivore/ bittercress interaction', Oecologia 79(1), 111-116. https://doi.org/10.1007/ BF00378247

Colwell, R.K., 2013, 'Estimates: Statistical estimation of species richness and shared species from samples', Version 9, User's Guide and application, viewed 25 June 2015, from https://purl.oclc.org/estimates.

Danks, H.V., 1994, 'Diversity and integration of life-cycle controls in insects', in H.V. Danks (ed.), Insect life-cycle polymorphism: Theory, evolution and ecology consequences for seasonality and diapause control, pp. 5-40, Kluwer Academic publishers, Dordrechrt.

DeClerck, F.A.J. \& Salinas, A.M., 2011, 'Measuring biodiversity', in B. Rapidel, F. DeClerck, J. Le Coq \& J. Beer (eds.), Ecosystem services from agriculture to agroforestry: Measurement and payment, pp. 91-118, Earthscan, London.

De Lange, H. \& Von Mollendorf, L., 2006, 'Current position of plant improvement in the honeybush tea industry', South African Honeybush Tea Association Newsletter No. $14,8-15$.

Den Hartigh, W., 2011, Honeybush industry set for growth, viewed 01 April 2014, from https://www.mediaclubsouthafrica.com/economy/2597-honeybush.

Department of Agriculture, Forestry and Fisheries (DAFF), 2014, A profile of the South African rooibos tea market value chain, Directorate Marketing, Pretoria, viewed 15 June 2014, from www.nda.agric.za/.../Marketing/.../Commodity\%20 Profiles/.../ROOIBOS

Dudhia, Z., Louw, J., Muller, C., Joubert, E., De Beer, D., Kinnear, C. et al., 2013 , 'Cyclopia maculata and Cyclopia subternata (honeybush tea) inhibits adipogenesis in 3T3-L1 pre-adipocytes', Phytomedicine 20(5), 401-408. https://doi.org/ 10.1016/j.phymed.2012.12.002
Du Toit, J., Joubert, E. \& Britz, T.J., 1998, 'Honeybush tea-a rediscovered indigenous South African herbal tea', Journal of Sustainable Agriculture 12(2-3), 67-84. https://doi.org/10.1300/J064v12n02_06

Esler, K.J., Pierce, S.M. \& De Villiers, C., 2014, Fynbos, Ecology and management, Briza Publications, Pretoria.

Forrest, J.R.K. \& James, D.T., 2011, 'An examination of synchrony between insect emergence and flowering in Rocky Mountain meadows', Ecological Monographs 81(3), 469-491. https://doi.org/10.1890/10-1885

Gess, S.K. \& Gess, F.W., 2014, Wasps and bees in southern Africa, SANBI Biodiversity Series 24, South African National Biodiversity Institute, Pretoria, viewed 20 June 2014, from https://www.researchgate.net/publication/268818231_Wasps_and bees_in_southern_Africa.

Goldblatt, P., Manning, J.C. \& Snijman, D., 2005, 'Cape plants: Corrections and additions to the flora. 1', Bothalia 35(1), 35-46.

Goulet, H. \& Huber, J.T. (eds.), 1993, Hymenoptera of the world: An identification guide to families, Agricultural Canada, Ottawa.

Hatting, J.L., 2009, Insekte op Rooibos, 1st uitgawe, South African Rooibos Council, Cape Town, South Africa. ISBN 978-1-86849-410-1.

Hatting, J.L., 2015, 'Rooibos', in G.L Prinsloo \& V.M. Uys (eds.), Insects of cultivated plants and natural pastures in Southern Africa, pp. 298-309, Entomological Society of Southern Africa, Pretoria.

Hawkins, H.J., Malgas, R.R. \& Biénabe, E., 2011, 'Ecotypes of wild rooibos (Aspalathus linearis (Burm. F) Dahlg., Fabaceae) are ecologically distinct', South African Journal of Botany 77(2), 360-370. https://doi.org/10.1016/j.sajb.2010.09.014

Joubert, E., Gelderblom, W.C.A., Louw, A. \& De Beer, D., 2008, 'South African herbal teas: Aspalathus linearis, Cyclopia spp. and Athrixia phylicoides-a review', Journal of Ethnopharmacology 119(3), 376-412. https://doi.org/10.1016/j.jep.2008.06.014

Joubert, E., Joubert, M.E., Bester, C., De Beer, D. \& De Lange, J.H., 2011, ‘Honeybush (Cyclopia spp.): From local cottage industry to global markets: The catalytic and supporting role of research', South African Journal of Botany 77(4), 887-907. https://doi.org/10.1016/j.sajb.2011.05.014

Kies, P., 1951, 'Revision of the genus Cyclopia and notes on some other sources of bush tea', Bothalia 6(1), 161-176, viewed 15 April 2014, from https://abcjournal. org/index.php/ABC/article/download/1685/1650.

Kruger, F.J., 1984, 'Effects of fire on vegetation structure and dynamics', in P.V. De Booysen \& N.M. Tainton (eds.), Ecological effects of fire in South African ecosystems, pp. 219-243, Ecological Studies (Analysis and Synthesis) 48, Springer, ecosystems, pp. 219-243, Ecological Studies (Analysis and Synthesis)

Laikre, L., Schwartz, M.K., Waples, R.S. \& Ryman, N., 2010, 'Compromising genetic diversity in the wild: Unmonitored large-scale release of plants and animals', Trends in Ecology and Evolution 25(9), 520-529. https://doi.org/10.1016/j.tree.2010.06.013

Larsen, P.M., Fey, S.J., Louw, J. \& Joubert, L., ZADEC APS, 2011, Anti-diabetic extract of honeybush, U.S. Patent Application 12/531,028.

Louw, R., 2006, 'Sustainable harvesting of wild rooibos (Aspalathus linearis) in the Suid Bokkeveld, Northern Cape', Unpublished MSc dissertation, Botany Department, University of Cape Town.

Malgas, R.R., Potts, A.J., Oettlé, N.M., Koelle, B., Todd, S.W. \& Verboom, G.A., 2010, 'Distribution, quantitative morphological variation and preliminary molecular analysis of different growth forms of wild rooibos (Aspalathus linearis) in the northern Cederberg and on the Bokkeveld Plateau', South African Journal of Botany 76(1), 72-81. https://doi.org/1016/j.sajb.2009.07.004

Mallet, J., 2008, 'Hybridization, ecological races and the nature of species: Empirical evidence for the ease of speciation', Philosophical Transactions of the Royal Society B: Biological Sciences 363(1506), 2971-2986. https://doi.org/10.1098/ rstb.2008.0081

Manning, J., 2018, Field guide to fynbos, Penguin Random House South Africa, South Africa. ISBN. 9781775845904

McGregor, G., 2017a, An overview of the honeybush industry, Western Cape Department of Environmental Affairs and Development Planning, Cape Town, Department of Environmental Affairs and Development Planning, Cape Town,
viewed 13 June 2019, from https://www.westerncape.gov.za/eadp/files/atoms/ viewed 13 June 2019, from https://wwW.westerncape.gov.za/eadp/files/at
files/eadp696_an_overview_of_the_honeybush_industry_may2017_0.pdf.

McGregor, G., 2017b, Guidelines for the sustainable harvesting of wild honeybush, Western Cape Department of Environmental Affairs and Development Planning, Cape Town, viewed 13 June 2019, from https://www.westerncape.gov.za/eadp/ files/atoms/files/eadp696_guidelines_for_the_sustainable_harvesting_of_wild_ files/atoms/files/eadp696

Motsa, M.M., Slabbert, M.M., Bester, C. \& Ngwenya, M.Z., 2016, 'Phenology of honeybush (Cyclopia genistoides and C. subternata) genotypes', South African Journal of Botany 110(2017), 57-67. https://doi.org/10.1016\%2Fj.sajb.2016.03.005

Mustart, P., 2000, 'Life after death in Fynbos', Veld and Flora 82(2), 73-75. https:// journals.co.za/content/veld/86/2/AJA00423203_2619

Ojeda, F., 1998, 'Biogeography of seeder and resprouter Erica species of the Cape Floristic region: Where are the resprouters?', Biological Journal of the Linnean Society 63(3), 331-347. https://doi.org/10.1111/j.1095-8312.1998.tb01521.x

Pierce, S.M., 1984, A synthesis of plant phenology in the Fynbos biome, South African National Scientific programmes Report 88, Graphics Art Division of the CSIR Pretoria.

Pilar, C.-D. \& Gabriel, M.-M., 1998, 'Phenological pattern of fifteen Mediterranean phanerophytes from Quercus ilex communities of NE-Spain', Plant Ecology 139 103-112, viewed 13 June 2019, from http://www3.uah.es/dep_ecologia_pcastro/ Curriculum/11.\%20Publicaciones/11.\%20Plant\%20Ecology\%2098.pdf.

Potts, A.J., 2016, 'Genetic risk and the transition to cultivation in Cape endemic crops - The example of honeybush (Cyclopia)?', South African Journal of Botany 110(2017), 52-56. https://doi.org/10.1016/j.sajb.2016.09.004 
Power, S.C., Cramer, M.D., Verboom, G.A. \& Chimphango, S.B.M., 2011, 'Legume seeders of the Cape Floristic region inhabit more fertile soils than congeneric
resprouters-sometimes', Plant Ecology 212(12), 1979-1989. https://doi. org/10.1007/s11258-011-9958-3

Prinsloo, G.L., 1980, An illustrated guide to the families of African Chalcidoidea (Insecta: Hymenoptera), Department of Agriculture and Fisheries Science, Bulletin, no. 395.

Prinsloo, G.L., 1984, An illustrated guide to the parasitic wasps associated with citrus pests in the Republic of South Africa, Department of Agriculture and Fisheries Science, Bulletin no. 402.

Rieseberg, L.H., 1997, 'Hybrid origins of plant species', Annual Review of Ecology and Systematics 28(1), 359-389. https://doi.org/10.1146/annurev.ecolsys.28.1.359

Rieseberg, L.H. \& Carney, S.E., 1998, 'Plant hybridization (Tansley review no. 102)', New Phytologist 140(4), 599-624. https://doi.org/10.1046/j.1469-8137.1998.00315.x

Rust, D.J. \& Myburgh, A.C., 1989, 'Rooibos tea (red tea) and Buchu pests. 21', in A.C. Myburgh (ed.), Crop pests in southern Africa Bulletin 416: Field crops and pastures, p. 4, Department of Agriculture and Water Supply, Plant Protection Research Institute, Pretoria.

Scholtz, C.H. \& Holm, E. (eds.), 1985, Insects of southern Africa, Butterworth, Durban.

Schutte, A.L., Vlok, J.H.J. \& Van Wyk, B.-E., 1995, 'Fire-survival strategy: A character of taxanomic, ecological and evolutionary importance in fynbos legumes', Plant Systematics and Evolution 195(3), 243-259. https://doi.org/10.1007/BF00989299

Schutte, A.L., 1997, 'Systematics of the genus Cyclopia Vent. (Fabeacea, Podalyrieae)', Edinburgh Journal of Botany 54(2), 125-170. https://doi.org/10.1017/ S0960428600004005

Seehausen, O., Takimoto, G., Roy, D. \& Jokela, J., 2008, 'Speciation reversal and biodiversity dynamics with hybridization in changing environments', Molecular Ecology 17(1), 30-44. https://doi.org/10.1111/j.1365-294X.2007.03529.x

Sivertsen, T.H., Nejedlik, P., Oger, R. \& Sigvald, R., 1999, The phenology of crops and the development of pests and diseases, viewed 08 August 2014, from https:// www.bioforsk.no/ikbViewer/Content/16776/Publikasjon1999.pdf.

Snodgrass, G., Jackson, R., Perera, O., Allen, K. \& Luttrell, R., 2012, 'Effect of food and temperature on emergence from diapause in the tarnished plant bug (Hemiptera: Miridae)', Environmental Entomology 41(6), 1302-1310. https://doi.org/10.1603/ EN11332
Son, Y., 1999, 'Modeling temperature-dependent development and survival of Otiorhynchus sulcatus (Coleoptera: Curculionidae)', Agricultural and Forest Otiorhynchus sulcatus (Coleoptera: Curculionidae)', Agricultural and Forest
Entomology 7(3), 201-209. https://doi.org/10.1111/j.1461-9555.2005.00260.x

Spriggs, A. \& Dakora, F.D., 2009, 'Symbiotic performance of selected Cyclopia Vent. (Honeybush) rhizobia under nursery and field conditions', Symbiosis 48(1), 143-153. https://doi.org/10.1007/BF03179993

Statsoft Inc., 2012, Statistica (Data analysis software system), Tulsa, USA, Statsoft Inc.

Stevens, N.B., Stephens, C.J., Iqbal, M., Jennings, J.T., LaSalle, J. \& Austin, D., 2007 'What wasp is that? An interactive guide to the Australian families of Hymenoptera', Australian Biological Resources Study/Centre for Biological Information. ISBN-10: 0642568510

Van der Walt, L., 2000, 'Cyclopia genistoides', Plantz Africa, viewed 01 April 2015, from https://www.plantzafrica.com/plantcd/cyclopiagenistoides.htm.

Van Wyk, B.E., 2008, 'A broad review of commercially important southern African medicinal plants', Journal of Ethnopharmacology 119 (3), 342-355. https://doi. org/10.1016/j.jep.2008.05.029

Van Wyk, B.E., 2011, 'The potential of South African plants in the development of new medicinal products', South African Journal of Botany 77(4), 812-829. https://doi. org/10.1016/j.sajb.2011.08.011

Van Wyk, B.E. \& Gorelik, B., 2016, 'The history and ethnobotany of Cape herbal teas', South African Journal of Botany 110(2017), 18-38. https://doi.org/10.1016/j. sajb.2016.11.011

Verdaguer, D. \& Ojeda, F., 2002, 'Root starch storage and allocation patterns in seeder and resprouter seedlings of two Cape Erica (Ericaceae) species', American Journal of Botany 89(8), 1189-1196, viewed 13 June 2019, from https://www.ncbi.nlm. nih.gov/pubmed/21665719.

Wardell-Johnson, G.W., 2000, 'Responses of forest eucalypts to moderate and high intensity fire in the Tingle Mosaic, south-western Australia: Comparisons between locally endemic and regionally distributed species', Austral Ecology 25(4) 409-421. https://doi.org/10.1046/j.1442-9993.2000.01049.x

Willmer, P.G. \& Stone, G.N., 2004, 'Behavioral, ecological, and physiological determinants of the activity patterns of bees', Advances in the Study of Behavio 34, 47-466. https://doi.org/10.1016/S0065-3454(04)34009-X 


\section{Appendix 1}

TABLE 1-A1: Phenology of two honeybush species (wild Cyclopia maculata $[n=240]$ and cultivated Cyclopia genistoides [ $n=180]$ ), representing reseeder and resprouter fire-survival strategies, respectively.

\begin{tabular}{|c|c|c|c|c|c|c|c|c|c|c|c|}
\hline \multirow[t]{2}{*}{ Species } & \multirow[t]{2}{*}{ Phenology phase } & \multirow{2}{*}{$\frac{\text { Jul/Aug }}{\text { Avg. } \%( \pm S D)}$} & \multirow[t]{2}{*}{$\%$ range } & \multirow{2}{*}{$\frac{\text { Oct }}{\text { Avg. } \%( \pm S D)}$} & \multirow[t]{2}{*}{$\%$ range } & \multirow{2}{*}{$\frac{\text { Dec }}{\text { Avg. } \%( \pm S D)}$} & \multirow[t]{2}{*}{$\%$ range } & \multirow{2}{*}{$\frac{\text { Feb }}{\text { Avg. } \%( \pm S D)}$} & \multirow{2}{*}{$\%$ range } & \multirow{2}{*}{$\begin{array}{c}\text { Apr } \\
\text { Avg. } \%( \pm S D)\end{array}$} & \multirow[t]{2}{*}{$\%$ range } \\
\hline & & & & & & & & & & & \\
\hline \multirow[t]{12}{*}{ C. maculata } & New leaves & $4 \pm 8$ & $10-30$ & $42 \pm 32$ & $10-30$ & $46 \pm 19$ & $60-80$ & $33 \pm 11$ & $80-90$ & $64 \pm 47$ & 70-90 \\
\hline & Mature leaves & $99 \pm 35$ & $90-100$ & $87 \pm 3$ & $90-100$ & $63 \pm 13$ & $80-90$ & $59 \pm 42$ & $80-90$ & $16 \pm 33$ & $0-30$ \\
\hline & Leaf shedding & - & - & $8 \pm 13$ & $0-20$ & $67 \pm 58$ & $0-10$ & $64 \pm 48$ & 80-90 & $67 \pm 50$ & $60-80$ \\
\hline & Early budding & $38 \pm 15$ & $90-100$ & - & - & - & - & - & - & $24 \pm 31$ & $20-30$ \\
\hline & Mature budding & $63 \pm 16$ & $90-100$ & $24 \pm 35$ & $20-50$ & - & - & - & - & - & - \\
\hline & Late budding & - & - & $6 \pm 7$ & $10-20$ & - & - & - & - & - & - \\
\hline & Initial flowering & - & - & $3 \pm 5$ & $0-20$ & - & - & - & - & - & - \\
\hline & Peak flowering & - & - & $33 \pm 24$ & 70-90 & $5 \pm 10$ & $0-20$ & - & - & - & - \\
\hline & Flower senescence & - & - & $43 \pm 41$ & $60-80$ & $99 \pm 2$ & $90-100$ & - & - & - & - \\
\hline & Seed set & - & - & $26 \pm 22$ & $50-70$ & & & - & - & - & - \\
\hline & Popped seed & - & - & - & - & $100 \%$ & $100 \%$ & - & - & - & - \\
\hline & Dying or dead & - & - & - & - & - & $0-10$ & - & $0-20$ & - & $0-30$ \\
\hline \multirow[t]{12}{*}{ C. genistoides } & New leaves & - & - & $20 \pm 35$ & $0-10$ & $43 \pm 4$ & $80-100$ & $18 \pm 5$ & $90-100$ & $43 \pm 42$ & 80-90 \\
\hline & Mature leaves & $100 \pm 0$ & $90-100$ & $97 \pm 35$ & $90-100$ & $61 \pm 7$ & $90-100$ & $84 \pm 2$ & $90-100$ & $10 \pm 17$ & $0-10$ \\
\hline & Leaf shedding & - & - & - & - & $29 \pm 6$ & 90-100 & $25 \pm 22$ & $90-100$ & $23 \pm 40$ & $20-30$ \\
\hline & Early budding & $92 \pm 7$ & $90-100$ & $12 \pm 8$ & $0-10$ & - & - & - & - & - & - \\
\hline & Mature budding & - & - & $40 \pm 49$ & $10-30$ & - & - & - & - & - & - \\
\hline & Late budding & - & - & $2 \pm 3$ & $0-10$ & - & - & - & - & - & - \\
\hline & Initial flowering & - & - & $12 \pm 13$ & $0-10$ & - & - & - & - & - & - \\
\hline & Peak flowering & - & - & $63 \pm 16$ & 70-90 & $11 \pm 13$ & $20-40$ & - & - & - & - \\
\hline & Flower senescence & - & - & $32 \pm 17$ & 70-90 & $96 \pm 5$ & $90-100$ & - & - & - & - \\
\hline & Seed set & - & - & $32 \pm 28$ & $30-40$ & - & - & - & - & - & - \\
\hline & Popped seed & - & - & - & - & $100 \%$ & $100 \%$ & - & - & - & - \\
\hline & Dying or dead & - & - & - & - & - & 0 & - & - & - & - \\
\hline
\end{tabular}

Note: Field sites were in the Overberg, South Africa. Data indicate the average percentage of a bush (Avg. \%) within the monitored population that was categorised to be within the respective phenology phase along with the standard deviation (SD) of the observations and the percentage range (\% range) of the overall population within the specific phenological phases. 